\title{
A NEW PSEUDANOPHTHALMUS FROM AN EPIGEAN ENVIRONMENT IN WEST VIRGINIA (COLEOPTERA : CARABIDAE) ${ }^{1}$
}

\author{
By Thomas C. Barr, Jr. \\ Department of Zoology, University of Kentucky
}

Eyeless, rufotestaceous cave beetles of the genus Pseudanophthalmus ('Trechini) are widespread in the Appalachian valley and Interior Low Plateaus (Barr, I965; Jeannel, I949; Valentine, I945). Geographic isolation in different cave systems has led to an unusually large number of species, presumably the slightly modified descendants of edaphic ancestors which existed outside caves during the cold, wet climates of Pleistocene glacial maxima (Barr, I965; Jeannel, 1949). Numerous species of other genera of trechine beetles, showing a more or less pronounced rudimentation of eyes and melanin pigments, are known from habitats other than caves, in mountainous glacial refugia of Europe and Japan (Jeannel, 1926-1930; Uéno and Baba, I965). One species group of Pseudanophthalmus - not confined to caves but exhibiting similar reduction of eyes and pigment inhabits humus and the upper soil strata at altitudes above rooo meters in the Carpathians and Transylvanian Alps of eastern Europe (Barr, 1964). Blind, depigmented trechines have not been previously reported from Nearctic regions except in caves, although Barr ( I965) recently commented: "It is conceivable that intensive collecting of endogenous carabids in the higher mountains of West Virginia and southwestern Virginia might reveal one or more surviving epigean populations of Pseudanophthalmus."

The purpose of this paper is to report the discovery of an eyeless, rufotestaceous, previously undescribed species of Pseudanophthalmus in an endogean habitat in the mountains of Pocahontas Co., West Virginia, and briefly to indicate its ecological and evolutionary significance. Three specimens were obtained from wet sand and gravel beneath medium-sized stones at the margin of a small brook on the east slope of Kennison Mountain, 28 April 1967. The locality is 7.2 kilometers NNE of Lobelia, in the Yew Mountains, Monongahela National Forest, about 300 meters west of the southwest corner of the Cranberry Glades, at an elevation of Iooo meters, Soil and

\footnotetext{
${ }^{1}$ This investigation was supported by a grant from the National Science Foundation (GB-5521).
}

Manuscript received by the editor May 12, 1967 
water temperature was $8^{\circ}-10^{\circ} \mathrm{C}$. The stream flows over sandstones and shales throughout its short length, and in the area where the beetles were collected it traverses a second-growth, mixed hemlock and deciduous forest with an estimated gradient of IOO meters per kilometer. The nearest exposures of limestone and consequently the nearest known caves are in the vicinity of Lobelia and Hillsboro, 7 to 9 kilometers to the south, and the vicinity of Buckeye, Io kilometers east. Troglomorphic collembolans - Sinella hoffmani Wray (det. K. Christiansen) - were found under the same stones with the beetles, and are here recorded for the first time outside of a cave.

The possibility that the beetles were washed out of one of these caves, in the manner described by Barr and Peck (1965) for an Alabama cave Pseudanophthalmus sp., is easily excluded, since the caves are situated at elevations 250 to 300 meters lower than the Kennison Mountain locality, and are in different drainage basins. Furthermore, examination of more than 1000 specimens of Pseudanophthalmus spp. from caves of the Greenbrier valley has not revealed the presence of the species taken at Kennison Mountain. The occurrence of 3 specimens in close proximity to each other is additional evidence that the habitat is a normal one for the species.

The new species is most closely similar to $P$. fuscus Valentine (1931 : p. 254), a species which inhabits caves of Pocahontas, Greenbrier, and Monroe counties, West Virginia, south of the Yew Mountains. It is readily differentiated, however, on the basis of the male genitalia and on other characters cited below. Although nominate $P$. fuscus shows no trace of an eye rudiment seen in the new species, undescribed subspecies of $P$. fuscus (or closely similar species) have a similar rudiment and the diagnosis must be made on the basis of other characters. P. fuscus is larger, more slender, and more densely pubescent, and the apex of its aedeagus is distinctively produced and more prominently knobbed.

\section{Pseudanophthalmus sylvaticus Barr, new species}

Figs. I, 2

Closely similar to $P$. fuscus Val., differing in smaller size, less rounded head, the entirely glabrous pronotal disc, the more subdued anterior angles of the pronotum, the more rounded margins of the pronotum with shorter oblique portion and deeper antebasal sinuation, the more distinct longitudinal striae of the elytra, the less closely spaced humeral set of umbilicate punctures, the thicker and shorter segments of the antennae, and the shorter aedeagus without conspicuously produced and knobbed apex. 


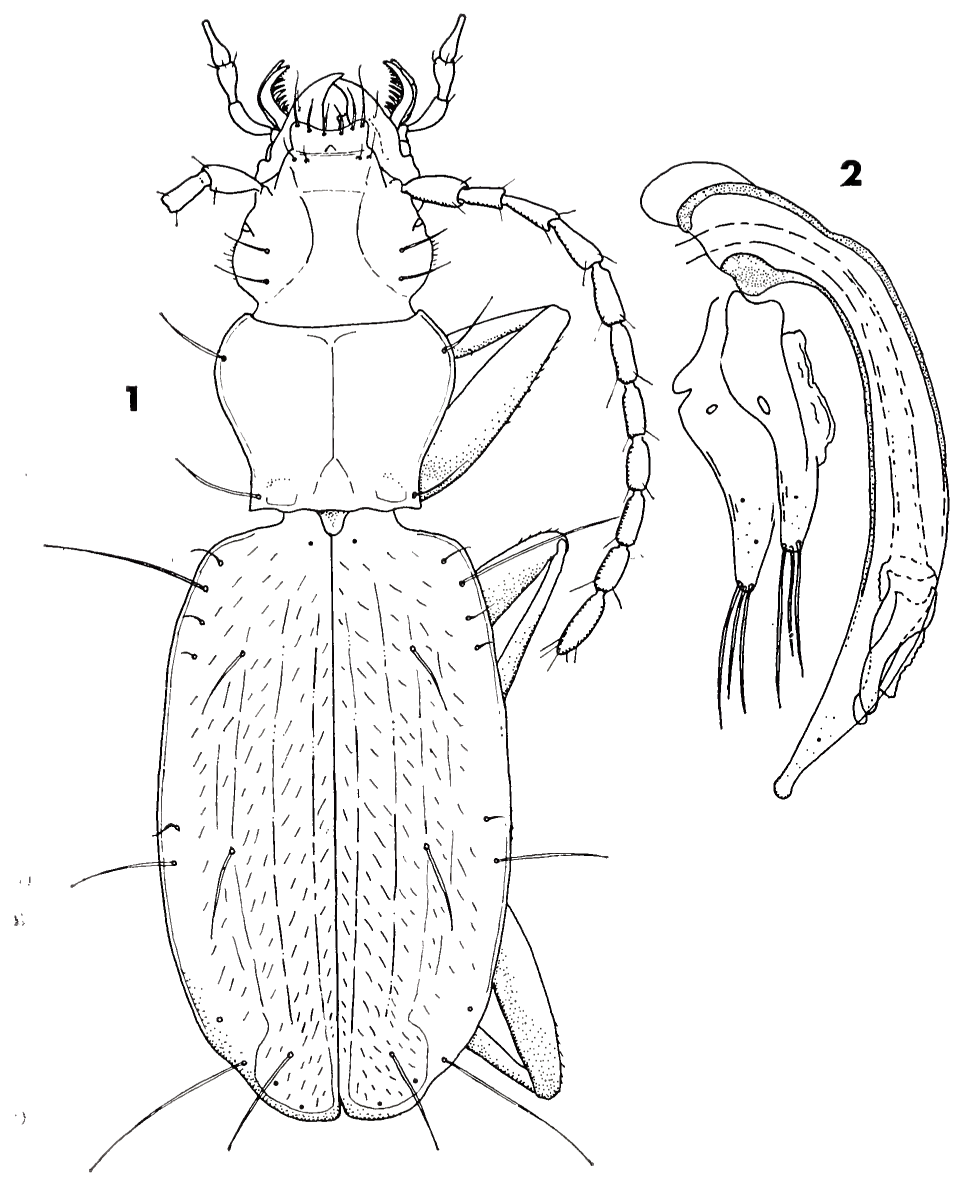

Figures 1 and 2. Pseudanophthalmus sylvaticus Barr, n. sp. 1. Female paratype, length $4.1 \mathrm{~mm}$. 2. Aedeagus, male holotype, length $0.74 \mathrm{~mm}$.

Length 4.08-4.12 mm. Form oblong, depressed. Rufotestaceous, shining. Dorsum of head and pronotal disc glabrous except for fixed setigerous punctures, elytra densely and finely pubescent. Microsculpture isodiametric on head, a very fine transverse meshwork on discs of pronotum and elytra. Head depressed, slightly transverse, conspicuously widest in basal third (widest at middle in $P$. fuscus); labrum evenly emarginate; eye rudiment present as a pale, lemon shaped areola $0.06 \times 0.04 \mathrm{~mm}$. Pronotum transversely cordiform, I I/4 times wider than long; width at apex 7/10 the maximum 
width, which occurs at apical fifth; base a little more than $9 /$ io as wide as apex; margins strongly rounded in apical half (in apical third in P. fuscus), then oblique, subparallel in basal sixth; hind angles prominent, right, sharp, and reflexed, the paramedian foveae deep; base feebly emarginate between hind angles. Elytra elongateelliptic, length I $3 / 5$ times combined width; prehumeral borders slightly oblique to mid-line, humeri somewhat angular but rounded, humeral margins setose but not serrulate; disc with 5 or 6 irregular rows of pubescence on each interval; longitudinal striae broadly and very shallowly impressed (obsolescent in P. fuscus); distance between Ist and 4 th umbilicate punctures $4 / 5$ the distance between 4 th and 5 th punctures (3/5 in P. fuscus) ; anterior discal puncture at level of 4 th umbilicate puncture, both anterior and posterior discals in 3 rd stria; recurrent portion of apical groove short, rounded to subparallel, bending sharply inward to apex of 3 rd stria at its anterior terminus; anterior apical puncture posteromedial to juncture of recurrent groove and 3rd stria. Appendages: antenna $5 /$ I I the total body length, outer segments rather short and thick, 9 th segment $3 / 5$ as wide as long ( $1 / 3$ in $P$. fuscus), densely pubescent; mentum tooth broad with apex emarginate; legs long and slender, but proportionately less slender than in P. fuscus. Male with secondary sex characters normal. Aedeagus $0.74 \mathrm{~mm}$ long (holotype) (0.88-0.90 $\mathrm{mm}$ in P. fuscus); basal bulb moderately expanded, with constriction before median lobe; apex gradually attenuate and very finely knobbed, not produced and conspicuously knobbed as in $P$. fuscus; parameres moderately elongate, with 3 apical setae; the middle one shortest; internal sac virtually unarmed, copulatory sclerites \pm lobulate as in $P$. fuscus but shorter.

Holotype ox (United States National Museum) and 2 우 paratypes, east base of Kennison Mountain near the Cranberry Glades, elevation 1000 meters, Pocahontas Co., West Virginia, 28 April 1967 (T. C. Barr, leg.). Measurements of holotype: total length 4.I2 $\mathrm{mm}$, head $0.72 \mathrm{~mm}$ long $\times 0.74 \mathrm{~mm}$ wide, pronotum $0.72 \mathrm{~mm}$ long $X 0.96 \mathrm{~mm}$ wide, elytra $2.22 \mathrm{~mm}$ long $\times 1.40 \mathrm{~mm}$ (combined) wide, antenna $2.32 \mathrm{~mm}$ long, aedeagus $0.74 \mathrm{~mm}$ long.

The discovery of $P$. sylvaticus strongly favors the hypothesis (Barr, 1965) that the ancestors of Nearctic cave trechines had already undergone much eye and pigment reduction and become edaphobites (obligate inhabitants of soil and humus) before colonizing caves. Under a periglacial climate, trechines would have been much more widely distributed than at present. Following retreat of the glaciers, 
these beetles would have become progressively restricted to sinkholes, cave entrances, deep ravines, and to higher forests where the climate remains cool and moist in summer. As regional climate became still warmer, they could have survived at lower altitudes only in caves, becoming troglobites (obligate cavernicoles) or at higher altitudes, becoming edaphobites in humus and the upper layers of the soil. In either case, ecological mobility would be greatly reduced, with concomitant restriction of gene flow, and many local endemics would have evolved.

In most parts of eastern United States the regional climate has apparently become too warm for continued survival of edaphic trechines. Unlike Europe, there are few high areas in eastern United States near the margins of Pleistocene glaciation to serve as refugia for cryophilic insects. In eastern West Virginia the combination of extensive cavern development in the Greenbrier valley and the existence of mountainous areas 1000 to I 400 meters high has preserved the edaphic, as well as the spelean remnants of the periglacial trechine fauna.

The occurrence of $P$. sylvaticus under rocks embedded in stream gravels is particularly interesting, since many similar small streams of the Greenbrier basin plunge from sandstone mountains into the limestone valley below and disappear into caves or sinkholes. Some species of Pseudanophthalmus are commonly found in nearly identical microhabitats along subterranean streams in caves. The logical sequence of events in cave colonization is thus obvious, at least in the Greenbrier valley. The eventual discovery of one or more American Pseudanophthalmus spp. which exist equally well in both the soil and in caves would not be surprising.

Cave colonization by trechines in eastern United States - particularly in areas adjacent to high, forested mountains and plateaus may be somewhat more recent than commonly supposed. Much eye and pigment reduction may have taken place during adaptation to life in the soil of cool, moist forests. Eyespots are still present in $P$. grandis Val. (Greenbrier valley), in undescribed subspecies of P. fuscus Val. (Greenbrier valley), and in the species of the petrunkevitchi group of Pseudanophthalmus (Appalachian valley of Virginia; petrunkevitchi Val., hoffmani Barr, hortulanus Barr, vicarius Barr). It seems reasonable to suppose that the presence of these rudiments indicates more recent eye reduction than in completely eyeless species (all others in the genus). All of these species with eye rudiments 
inhabit caves in close proximity to mountains rooo to I 300 meters high.

The current view of extrinsic isolation in different cave systems (Barr, I965; Krekeler, I959; see also Barr, in press) assumes that dispersal of troglobites from one system to another can take place only via subterranean routes, so that caves in limestone outcrops separated by non-caverniferous clastics (as in the Appalachian valley) are thought to represent habitats between which gene flow cannot take place. Once a species becomes a troglobite, its geographic distribution is controlled by its ability to disperse through subterranean channels and crevices, which are far more prevalent in soluble rocks than in clastics. It must be stressed that the discovery of $P$. sylvaticus does not basically change this view. For the moment, it appears that edaphic Pseudanophthalmus spp. in the United States are rare and probably restricted to cold mountain forests in a relatively few favorable places. Certainly the prevalence of such species needs further investigation.

On the other hand, the occurrence of $P$. sylvaticus supports the theory that cave Pseudanophthalmus spp. are relicts of rather widely distributed populations of edaphobites which existed near glacial margins and which colonized (and survived in) various cave systems during the early stages of interglacials. The peculiar occurrence of P. illinoisensis (Barr and Peck, I966) in Hardin Co., Illinois, I 75 kilometers west of all other known species of the tenuis group, which inhabit southern Indiana and adjacent Kentucky, is understandable in these terms. $P$. illinoisensis is so similar to $P$. barberi Jeannel, from the Pennyroyal Plateau of Kentucky between Mammoth Cave and the Ohio River, that the two species almost certainly share a close common ancestry, yet they are separated by the Ohio River and more than 150 kilometers of terrane underlain by sandstones, shales, and coals. A similar, though less spectacular case involving a pair of undescribed species of the menetriesi group in Tennessee and Kentucky is under study; a widespread, polytypic species inhabiting caves of the upper Cumberland and Green River drainages is separated from a closely similar form inhabiting a single cave near the center of the Central Basin.

\section{Literature Cited}

Barr, ThOMAS C., JR.

1964. The status and affinities of Duvaliopsis Jeannel (Coleoptera: Carabidae). Psyche, $71(2):$ 57-64. 
1965. The Pseudanophthalmus of the Appalachian valley (Coleoptera: Carabidae). American Midl. Nat., 73 (1) : 41-72.

1967. In press. Observations on the ecology of caves. American Nat. Barr, Thomas C., Jr., and Stewart B. Peck.

1965. Occurrence of a troglobitic Pseudanophthalmus outside a cave (Coleoptera: Carabidae). American Midl. Nat., 73(1): 73-74.

1966. Discovery of Pseudanophthalmus (Coleoptera: Carabidae) in southern Illinois. Ibid., $76(2)$ : 519-522.

JEAN NEL, RENÉ.

1926-1930. Monographie des Trechinae. Morphologie comparée et distribution géographique d'un groupe de Coléoptères. L'Abeille, $32(3): 221-550 ; 33(1): 1-592 ; 34(2): 59-122 ; 35(1): 1-808$.

1949. Les coléoptères cavernicoles de la région des Appalaches. Etude systématique. Notes Biospéol., 4: 37-104.

Krekeler, Carl $\mathrm{H}$.

1959. Dispersal of cavernicolous beetles. Syst. Zool., 8: 119-130.

Uéno, Shun-IChi, and Kintaro Baba

1965. Occurrence of a new Kurasawatrechus (Coleoptera) in an endogean habitat. Bull. Nat. Sci. Mus. (Tokyo), 8(1): 17-21, pl. 1. VAlentine, J. Manson

1931. New cavernicole Carabidae of the subfamily Trechinae Jeannel. J. Elisha Mitchell Sci. Soc., 46: 247-258.

1945. Speciation and raciation in Pseudanophthalmus (cavernicolous Carabidae). Trans. Connecticut Acad. Arts \& Sci., 36: 631-672. 


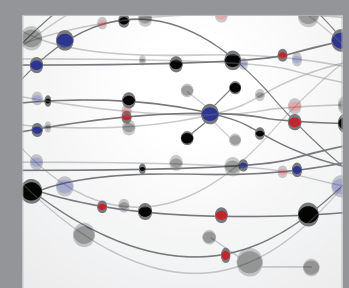

The Scientific World Journal

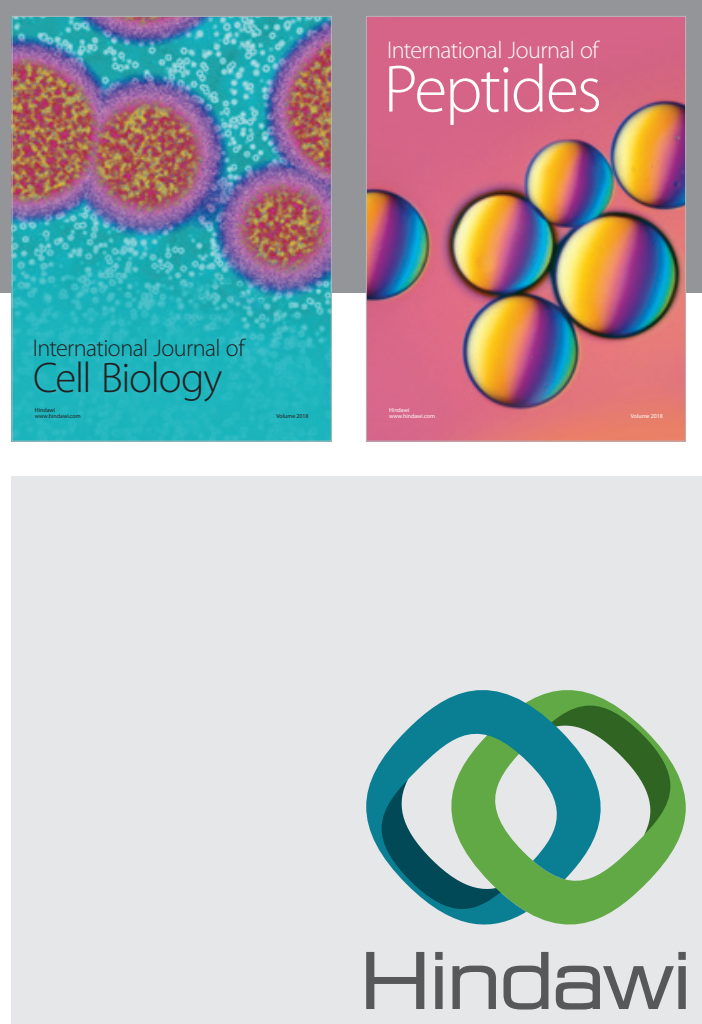

Submit your manuscripts at

www.hindawi.com
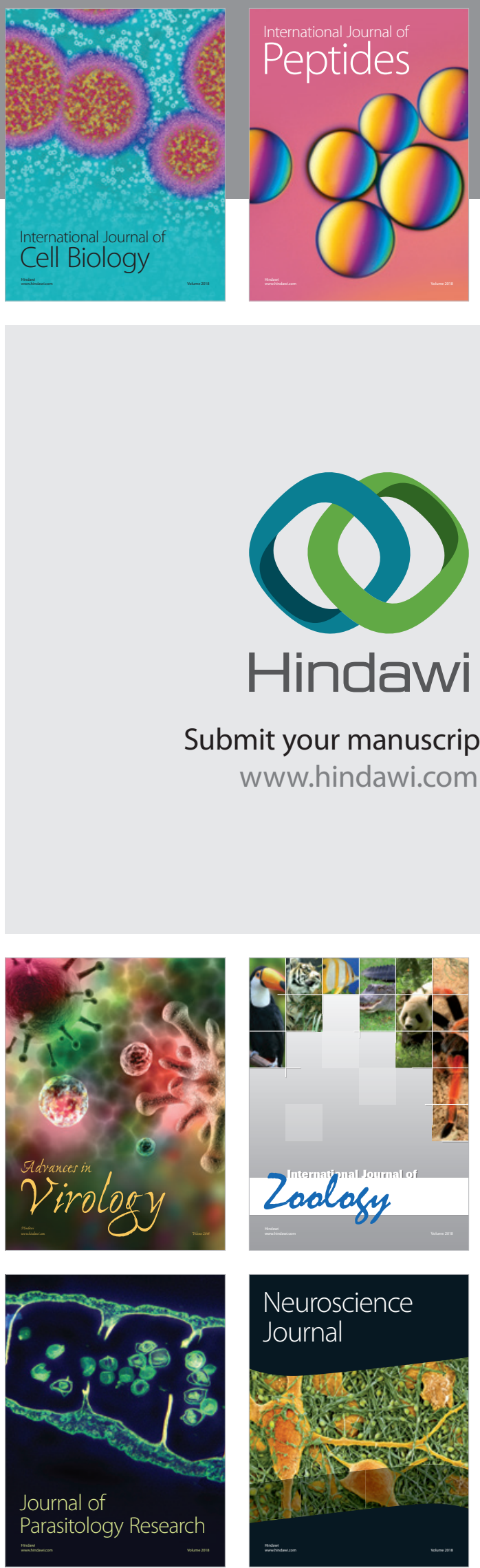
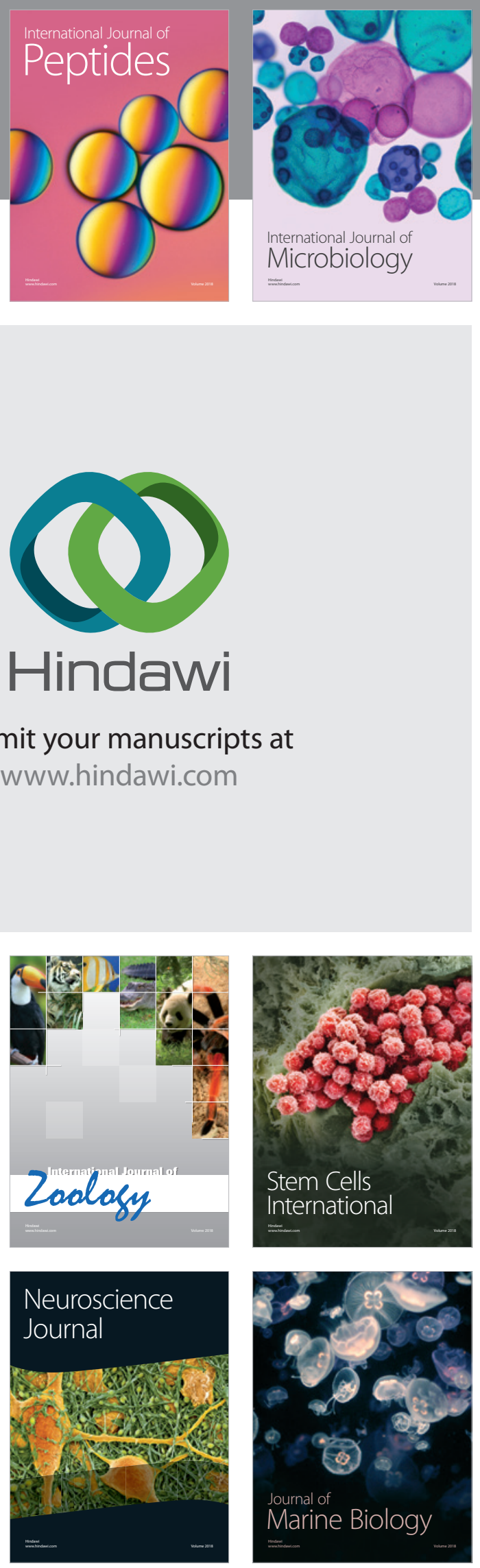
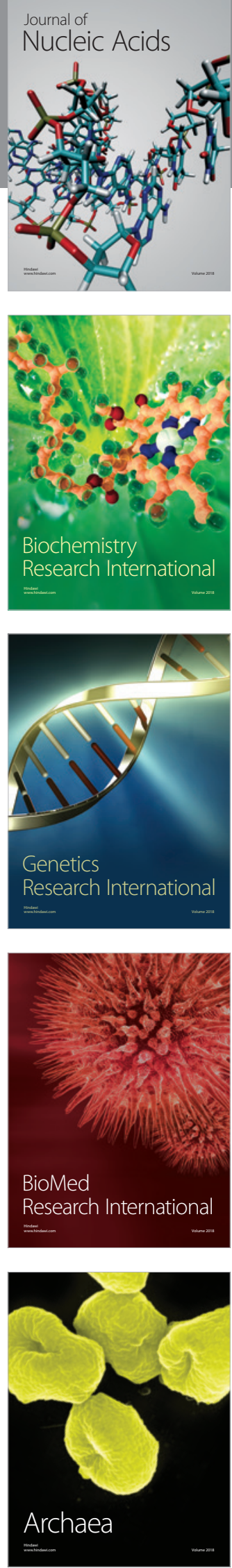